\title{
O Haliči v prostoru dějin, kultury, literatury a jazyka
}

Ivo Pospíšil (Brno)

Ve dnech 20.-21. 4. 2017 pořádal Institut regionální kultury a literárních bádání Franciszka Karpińského, Haličské kolegium a Pedagogická univerzita v Drohobyči ve spolupráci s univerzitou Siedlce mezinárodní konferenci o Haliči. Zúčastnili se jí badatelé z Polska, Ukrajiny, Rakouska a České republiky, kterou zastupoval autor této zprávy referátem o haličsko-bukovinské linii v díle brněnského slavisty Mečislava Krhouna o Juriji Fed'kovyčovi.

Konferenci zahájili Alois Woldan z Vídeňské univerzity, Volodymyr Kemiń ze spolupořádající Drohobyčské státní pedagogické univerzity a Roman Mnich z Univerzity Siedlce. Témata byla velmi podnětná a řešené otázky palčivé, at již šlo o referát Haliny Korbicz z Poznaně o geokulturním diskursu Haliče z ukrajinské pozice nebo Olafa Terpitze o Dubnovově Historii židovského vojáka nebo samotného Volodymyra Kemině o Haliči pod rusko-rakouskou okupací. Další témata nebyla o nic méně ostrá: týkala se náboženství, činnosti Ivana Franka (mj. referát Danuty Szymonik), polsko-ukrajinských vztahů, šovinismu, Haliče jako heterotopie Františka Josefa I. (Roman Mnich), polské a ukrajinské poezie o první světové válce (Alois Woldan), problému Huculů (Jaroslav Poliščuk); podnětný byl také srovnávací příspěvky Bogdana Zielińského a Andrzeje Borkowského, stejně jako historika Wacława Szymonika.

Přínosem konference byla její multidisciplinarita, vícejazyčnost (polština, ukrajinština, němčina, čeština, ruština), ostrá tematika, bohatá diskuse; problémem byla - podle mého názoru - absence badatelů z některých zemí, které mají k problematice Haliče blízko, tedy především z Ruska, Mad’arska a Německa. Jistě to bylo v současné politické situaci obtížné, ale kdyby se to podařilo, mohla být konference názorově pluralitnější, diskuse by byly ostřejší a bylo by snášeno více podstatných argumentů - zvláště mezi skutečnými vědci, kteří abstrahují od povrchních ideologií a aktuálních politických aspektů, by to měla být obvyklá věc. I tak měla konference o Haliči svůj smysl; její sevřený formát vytvořil plodnou, kolegiální atmosféru. Potvrdila se známá věc, že multikulturalismus nevznikl dnes nově jako ideologie nového světového pořádku, ale jde o běžný, každodenní, starobylý fakt celé Evropy, kulturní půda, z níž vycházely podněty, aniž by ovšem zahlazovaly hroty letitých sporů. Halič by tedy mohla být ve své diachronní podobě laboratoří takových výzkumů a současně varováním před nerealistickými, iluzorními představami v dnešním světě na pokraji nových válečných konfliktů.

prof. PhDr. Ivo Pospíšil, DrSc.

Ústav slavistiky

Filozofická fakulta, Masarykova univerzita

Arna Nováka 1, 60200 Brno, Česká republika

ivo.pospisil@phil.muni.cz 